\title{
The Impact of Information Systems Investment on Bank Performance in Ghana
}

\author{
Dr. Ebenezer Ankrah \\ Department of Information Studies \\ School of Information and Communication Studies, \\ College of Education, University of Ghana, Legon
}

\begin{abstract}
The advancement of technology is a necessity of the current era. Businesses need to adopt and embrace new technologies to provide excellent business operations and services to their customers. This study looks at the impact of information systems investment on bank performance in Ghana. The major objectives are; (1) to determine the types of technology that the banks invest in (2) to find out the level of IS investment in the banks and (3) to determine the relationship between IS investments and bank's performance. The following hypothesis was proposed and tested statistically "Information systems investment has a positive relationship with bank performance". This study adopted the survey methodology. Taking into account the purpose of the study and the research hypothesis, this study is comfortably placed within a scientific epistemology of logical positivism. The cases investigated were local banks and foreign banks. The six banks used were named Bank A, Bank B, Bank C, Bank D, Bank E and Bank $F$ respectively for the sake of anonymity. The population for the study was the strategic staff from the six banks all selected at their Head Offices in Greater Accra Region. The findings revealed that, there has been a high rate of investment in the past three years made by the various banks. The findings also revealed that both the foreign banks and the local banks asserted to the fact that, market share, profitability and ROA increases as IS investments are employed in the industry. Subjecting the hypothesis to statistical test also showed that, information systems investment has a positive relationship with bank performance. This study would help bank managers to recognize the importance of information systems investment and its use to gain competitive advantage and increase profit margins.
\end{abstract}

Key words: Information Systems Investment, Bank, Performance and Strategic Staff

\section{INTRODUCTION}

Today's business environment is very dynamic and undergoes rapid changes as a result of technological innovation, increased awareness and demands from customers. Over the last decade, the literature has emphasized the various roles of IT in fundamentally changing the way firms operate and in generating a strategic impact. One of the more important roles of IT is in extending the enterprise. IT can be used to transform organizational boundaries, interorganizational relations, and marketplace competitive and cooperative practices (Konsynski, 1993). Business organizations, especially the banking industry of the 21st century operates in a complex and competitive environment characterized by these changing conditions and highly unpredictable economic climate. The application of information and communication technology (ICT) concepts, techniques, policies and implementation strategies to banking services has become a subject of fundamental importance and concerns to all banks and indeed a prerequisite for local and global competitiveness. ICT directly affects how managers decide, how they plan and what products and services are offered in the banking industry. It has continued to change the way banks and their corporate relationships are organized worldwide and the variety of innovative devices available to enhance the speed and quality of service 
delivery. The banking sector has seen considerable transformation in the 1980s starting from the United States, then Europe and now the global village. The main forces behind this significant transformation in the banking industry, according to Reixach (2001), are deregulation and innovation in information technology (IT). Woherem (2000) claimed that only banks that overhaul the whole of their payment and delivery systems and apply ICT to their operations are likely to survive and prosper in the new millennium. He advices banks to re-examine their service delivery systems in order to properly position them within the framework of the dictates of the dynamism of information and communication technology. The banking industry in Ghana has witnessed tremendous changes linked with the developments in ICT over the years. The quest for survival, global relevance, maintenance of existing market share and sustainable development has made exploitation of the many advantages of ICT through the use of automated devices imperative in the industry.

The Ghanaian economy has experienced high influx rate of foreign banks in recent times. Banking operations are characterized with complexity and competition. To remain competitive, there is the need for a scientific approach in operations. One such an approach is information systems investment. Ghana has 27 universal banks, 135 rural banks and 49 nonbank financial institutions, including leasing firms, mortgage providers, finance houses, and savings and loan institutions and that is without counting the thousands of 'susu' collectors, who serve as informal, small-scale depository institution for market traders and shopkeepers. Of the 27 universal banks, 10 are locally owned while the remaining are backed by international owners; a mixture of European, American and African banking groups (The Report, Ghana 2014). Agboola (2003) indicated that the adoption of Information and Communication Technology in banks has improved customer services, facilitated accurate records, provided for home and office banking services, ensured convenient business hours, prompt and fair attention, and enhanced faster services. The adoption of ICT improves the banks' image and leads to a wider, faster and more efficient market. In Ghana, all the banks have information technology department that supports the various departments technologically. What still remains uncertain is whether the banks information systems investment commensurate the expected business performance. This study looks at the impact of information systems (IS) investment on bank performance in Ghana. The major objectives are; (1) to determine the types of technology that the banks invest in (2) to find out the level of IS investment in the banks and (3) to determine the relationship between IS investments and bank's performance. The following hypothesis was proposed and tested statistically "Information systems investment has a positive relationship with bank performance". This study would help bank managers to recognize the importance of information systems investment and its use to gain competitive advantage and increase profit margins.

\section{An overview of Information System in Banking}

\section{LITERATURE}

Although Information System expenditure is regarded as costly and risky, financial institutions are one of the largest investors in IS (Robson, 1997). The past 25 years have witnessed vast reductions in the cost of information technology. Between 1995 and 2005, the computing power of the average personal computer (PC) increased tremendously, while the price declined. The introduction of ATMs made the distribution of some banking services more efficient as it reduces time wastage in financial transactions. IT has developed the competition between financial institutions. Many new banking innovative strategies emerged from a new or enhanced banking information systems, which include e-banking, smartcard system or enhancement of other payment card system. Before the emergence of ATMs, withdrawing 
funds, account inquiries and transferring funds between accounts requires face-to-face interaction between the customer and a bank teller.

According to Gupta and Collins (1997), there are four popular efficiency measures used to assess MIS return, which are as follows: reduced operating expenses; increased profitability; increased fee income as percentage of total revenue and increased net-interest margin to average earning assets. Mitra and Chaya (1996) found that IT investments reduce average production costs, and increase average overhead costs in firms. Alpar and Kim (1990) reported that investments in information technology decrease total costs in the banking industry. Harris and Katz (1991) found that higher information technology spending is associated with lower growth in operating cost of insurance companies. An interesting finding of Morton (1991) supported by Hitt \& Brynjolfsson (1996) is that benefits from IT do in fact exist, but are not captured by the organization. Allen et al., (2006) pointed out that efficiency is measured in three ways: performance ratio, economy of scale, and cost efficiency, and according to Pehlivan \& Kirkpatrick (1990), functional efficiency in financial institutions is measured by the cost and profit margins.

The result of effective strategic management should be evident in the performance of the organization. Various works support the sustained evolution towards positions, which are more optimistic about the impact of IT (Brynjolfsson and Hitt, 2001; Brynjolfsson, Hitt and Yang, 2000). Researchers like Hitt and Brynjolfsson, admitted that IS investments were associated with an increase in productivity of works who work with information and additionally they claim that investments in computing generates greater levels of productivity than any other type of investments, despite the short life-span of this type of tool. However, the researchers maintain that the results obtained do not imply that investing in IT guarantees net productivity gains, but that other factors may influence the relation (Bruque et al., 2002). Hitt and Brynjolfsson (1996) discovered within the same period that there is no relation between growth in market share or business profit and investment in IT and even found slight negative correlation coefficients between both variable pairs.

Evidence showed a relationship between investment in IT and improvement in global business performance and productivity. (Brynjolfsson, Hitt and Yang, 2000; Brynjolfsson and Hitt, 2001). Using a global result indicator (Tobin's Q ratio) based on the firm's value in the stock market they concluded that those firms, which invested more in IT in the period 1987 - 1994, achieved superior results. More so the correlation was stronger when the firm, along with the investment in IT, underwent a structural reorganization involving interdisciplinary workgroups, increase in independent decision making and support for employee training. More recently, researchers began to find positive relationships between IT investment and various measures of economic performance.

Alpar and Kim (1991) in their study of 759 banks indicated that investment in IT has a cost reducing effect. They also found a $10 \%$ increase in IT capital is associated with $1.9 \%$ decrease in total costs. Increase in economics of scale as a contributing factor of IT was found in Pulley and Braunstein's (1984) study of information services firm as well. Barua et al., (1991) found IT was positively related to measures of performance, although the magnitude of the effect was generally too small to measurably affect final output. Alpar and Kim (1991) undertook a study and found out that, the problem of measuring the impact of information technology on economic performance at the business unit or enterprise level is receiving increased attention. Alpar and Kim (1991) developed a methodology based on the microeconomic theory of 
production and applied the model to data from the banking industry. In addition, they compare their methodology to approaches based on key ratios of information systems deployment. Both procedures were applied to the same set of data. The results show that reasoning about information systems value based on key ratios may be misleading, especially when the figures are only calculated for a cross-section of data.

\section{Information Systems and Performance}

Lee (2012) tried to find out whether the success of information systems really matters to firm performance. Many failed listed enterprises had strong information capabilities and resources. However, such advantage did not help these enterprises survive during the economy difficult times. Previous research of DeLone and McLean (2003) implied the success of information systems will enhance the performance of enterprises. Based on this implication, many enterprises continuously invested resources on information systems as a strategy trying to gain advantage over competitors. The net benefits in D\&M model resulted from the success of information system does not always significantly improve the enterprise performance but rather has a limit on it. In fact, such an excess investment cannot improve the enterprise performance but exhausts more valuable resources instead.

There have been many firm level studies examining the relationship between IT investment and firm performance over the last two (2) decades. Apart from Strassmann's (1997) report of disappointing evidence in several studies which he found that there was no correlation between IT and return on investment in a sample of 38 services sector firms, there are other reports of similar regards. Parsons et al., (1990) estimated a production function for banking services in Canada and found that the overall impact of IT on multifactor productivity was quite low between 1974 and 1987 and they posited that IT has positioned the industry for greater growth in the future. Franke (1987) reaching similar conclusions, found that IT was associated with a sharp drop in capital productivity and stagnation in labour productivity, but remained optimistic about the future prospects of IT, citing the long time lags associated with previous "technological transformation".

Karimi et al., (1996) argue that, recently the globalization of competition has caused many firms in the financial services industry to integrate their information systems. According to a survey of 213 managers, they find that competitive strategy, information technology (IT) maturity and size influence firms' perceived increase in IT investment. Further, they find that the degree of IT integration within firms is a primary determinant of firms' willingness to use IT as part of their strategic response to globalization. It suggests that the new competitive strategies will be increasingly technology-based global initiatives that are affected by the firms' IT maturity. Beccalli (2007) investigates whether investment in information technology (IT); hardware, software and other IT services influence the performance of banks. Using a sample of 737 European banks over the period 1995-2000, Beccalli (2007) analyzed whether IT investment is reflected in improved performance (measured using both standard accounting ratios and cost and alternative profit efficiency measures). Despite banks being major investors in IT, Beccalli (2007) found little relationship between total IT investment and improved bank profitability or efficiency indicating the existence of a profitability paradox. However, the impact of different types of IT investment (hardware, software and services) on banks' performance is heterogeneous. Investment in IT services from external providers (consulting services, implementation services, training and education, support services) appears to have a positive influence on accounting profits and profit efficiency, while the acquisition of hardware and software seems to reduce banks' performance. 


\section{Theoretical Framework}

A theory can be defined as a set of definitions and propositions that specify the relationship among variables. They help to explain or predict phenomena that occur in the world. A theory for a study guides the entire study, an organizing model for the research questions and for the data collection procedure (Creswell, 2003). The DeLone and McLean (2003) theoretical framework was used because it fits perfectly into the study and many authors have also used this model. Many studies have empirically tested the updated model (Tsai et al., 2012, Shareef et al., 2011, Pitt et al., 2011). The theoretical framework incorporates the following dimensions: systems quality, information quality, and service quality, intention to use, user satisfaction, and net benefits. The framework is as follows;

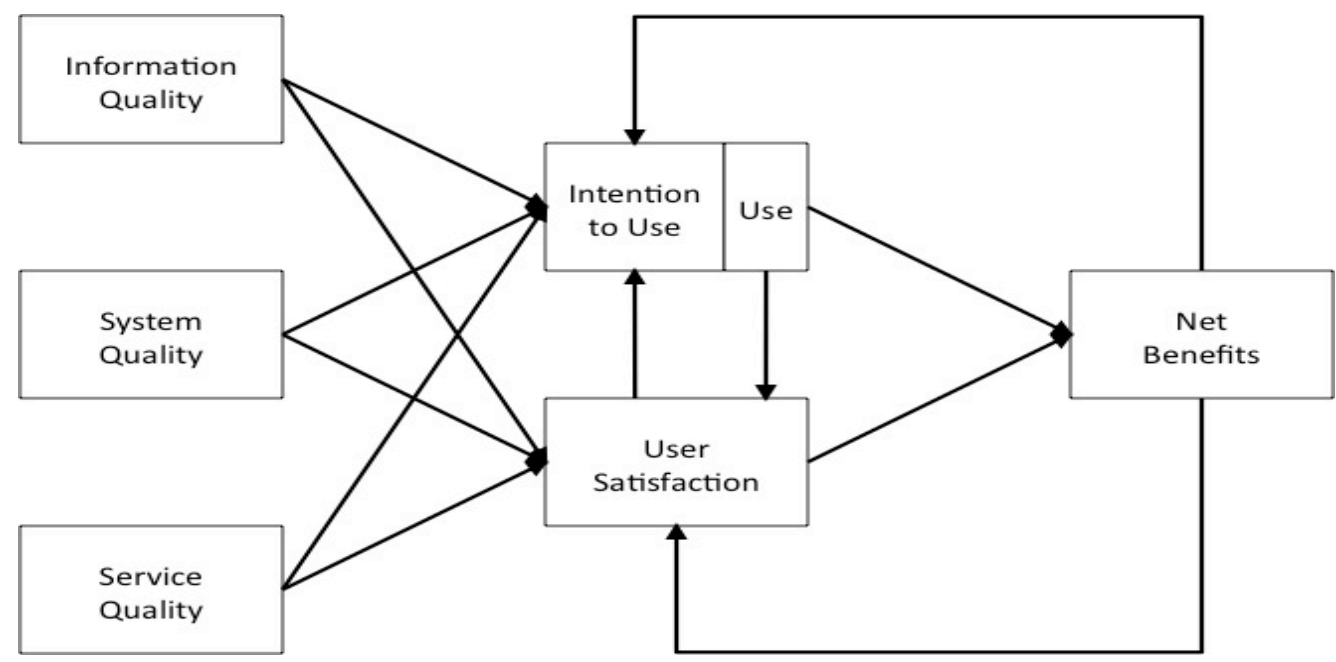

Figure 1: Information Systems Success Model (DeLone \& McLean 2003)

\section{METHODOLOGY}

This study adopted the survey methodology. The method allows the results of the study to be generalized from the sample perspective, to the entire population. Thus the results obtain also give high level of reliability. Taking into account the purpose of the study and the research hypothesis, this study is comfortably placed within a scientific epistemology of logical positivism because it allows IS researchers to answer research questions about the interaction of humans and computers and it also emphasis on quantitative data. The cases investigated were local banks and foreign banks. The local banks consist of Ghana Commercial Bank (GCB), Agricultural Development Bank (ADB), and National Investment Bank (NIB). The foreign banks consist of Stanbic Bank Ghana (Stanbic), Standard Chartered Bank (SCB) and Barclays Bank Ghana (BBG). The six banks used were named Bank A, Bank B, Bank C, Bank D, Bank E and Bank $F$ respectively for the sake of anonymity. The population for the study was the strategic staff since they are responsible for semi-structured type of decision making. All the strategic staff were considered at their Head Offices in Greater Accra region.

The total number of the strategic staff is sixty two (62). Since the population is so small the researcher decided to use all the strategic staff in the study. With adherence to a survey research methodology, this study used the questionnaire instrument. The Statistical Package for Social Sciences (SPSS) was used to analyze the data. A simple frequency, percentages and Chi-Square test of independence to ascertain the significance of the relationship between variables were used to present the results of the study. Ethics were observed accordingly in conducting this research. Introductory letters were sent to all the banks for permission to use them in the study. In the data collection process, informed consent of the respondents was 
sought and respondents were guaranteed anonymity and confidentiality by the researcher. All citations were duly acknowledged and all participants treated respectfully.

\section{MAJOR FINDINGS}

\section{Information Systems Investment in the Past Three Years}

The changing scene of information technology and information systems has made businesses to invest more in information systems. The strategic staff respondents being at the top management were asked to indicate the level of information system investment in the past three year. The analysis of their responses is presented in Table 1.

Table 1: Responses of Levels of IS Investment by banks in the Past Three Years

\begin{tabular}{|c|c|c|c|c|c|c|c|c|c|c|c|c|}
\hline \multirow{2}{*}{ No=32 } & \multicolumn{2}{|c|}{ Bank A } & \multicolumn{2}{|c|}{ Bank B } & \multicolumn{2}{c|}{ Bank C } & \multicolumn{2}{c|}{ Bank D } & \multicolumn{2}{c|}{ Bank E } & \multicolumn{2}{c|}{ Bank F } \\
\cline { 2 - 12 } & Freq & $\%$ & Freq & $\%$ & Freq & $\%$ & Freq & $\%$ & Freq & $\%$ & Freq & $\%$ \\
\hline Low & - & - & - & - & - & - & - & - & - & - & - & - \\
\hline Moderate & - & - & - & - & 1 & 20 & - & - & - & - & - & - \\
\hline High & 6 & 100.0 & 6 & 100.0 & 4 & 80 & 5 & 100.0 & 5 & 100.0 & 5 & 100.0 \\
\hline Total & 6 & 100.0 & 6 & 100.0 & 5 & 100.0 & 5 & 100.0 & 5 & 100.0 & 5 & 100.0 \\
\hline
\end{tabular}

Source: Field data, 2015

The responses from the strategic staff suggest that, there has been a high rate of investment in the past three years. One (20.0\%) of the respondents from Bank $\mathrm{C}$ also indicated that there has been a moderate investment in terms of information technology and information systems. The foreign banks have invested more in information systems than the local banks. Bank $\mathrm{C}$ also recorded moderate IS investment even though some of the respondent indicated that the IS investment is high. Despite banks being major investors in information systems, Beccalli (2007) found little relationship between total IS investment and improved bank profitability or efficiency indicating the existence of a profitability paradox. However, the impact of different types of IS investment (hardware, software and services) on banks' performance is heterogeneous. Investment in IS services from external providers (consulting services, implementation services, training and education, support services) appears to have a positive influence on accounting profits and profit efficiency. Harris and Katz (1991) indicate that firm performance was linked to the level of information systems investment intensity.

\section{Information Systems Investment in Recent Times}

The use of information technology is an integral part of enterprise management and operations. Spending or investments in information systems help enterprises stay on the cutting edge of the new tech to achieve better financial results. Investments in information systems can also provide certain intangible benefits such as improved customer care, increased time efficiency or better coordinated record keeping within an organization. Banks also invest in technology based on their needs. The strategic staff being the right respondents for this question were asked to indicate IS investments in recent times. The responses of these staff are analyzed and presented in Table 2 . 
Table 2: Response on Information System Investments in Recent Times by Banks

\begin{tabular}{|c|c|c|c|c|c|c|c|c|c|c|c|c|}
\hline \multirow[t]{2}{*}{ No $=32$} & \multicolumn{2}{|c|}{ Bank A } & \multicolumn{2}{|c|}{ Bank B } & \multicolumn{2}{|c|}{ Bank C } & \multicolumn{2}{|c|}{ Bank D } & \multicolumn{2}{|c|}{ Bank E } & \multicolumn{2}{|c|}{ Bank F } \\
\hline & Freq & $\%$ & Freq & $\%$ & Freq & $\%$ & Freq & $\%$ & Freq & $\%$ & Freq & $\%$ \\
\hline $\begin{array}{l}\text { Banking } \\
\text { Software }\end{array}$ & 6 & 100.0 & 5 & 83.3 & 3 & 60.0 & - & - & - & - & - & - \\
\hline $\begin{array}{c}\text { Network } \\
\text { Infrastructure }\end{array}$ & - & - & - & - & 1 & 20.0 & 5 & 100.0 & 3 & 60.0 & 3 & 85.7 \\
\hline $\begin{array}{c}\text { Server } \\
\text { Computers }\end{array}$ & - & - & - & - & - & - & - & - & 1 & 20.0 & 1 & 5.7 \\
\hline Work Stations & - & - & - & - & - & - & - & - & 1 & 20.0 & 1 & 8.6 \\
\hline $\begin{array}{c}\text { IT } \\
\text { Outsourcing }\end{array}$ & - & - & 1 & 16.7 & 1 & 20.0 & - & - & - & - & - & - \\
\hline Total & 6 & 100.0 & 6 & 100.0 & 5 & 100.0 & 5 & 100.0 & 5 & 100.0 & 5 & 100.0 \\
\hline
\end{tabular}

Source: Field data, 2015

All the foreign banks have invested in network infrastructure in recent times. Bank E and Bank $F$ in addition to the network infrastructure have invested in servers and work / client stations. The local banks on the other hand have invested in improved banking software. In addition, Bank B has also invested in IT outsourcing activities like ATM services and general maintenance. Bank $\mathrm{C}$ has also in addition to the improved banking software has invested in network infrastructure and IT outsourcing activities. The researcher further asked the strategic staff about future IS investments. The respondents indicated that the bank has plans to improve upon the current information system and therefore in the future Bank C and Bank D would invest in electronic payment, electronic banking items and customer relationship systems to improve on the existing systems. Bank B and Bank E would also invest in support treasury dealing system and anti-money laundry systems. Bank A and Bank F would invest in Flexcube, IT security tools, and ATMs that take deposits in the near future.

\section{Effect of Information Systems Investment on Bank Performance}

Information systems investments have both positive and negative impacts on the operations of banks in the financial industry. The positive impact indicated here refers to reduction in operating expenses in market share, positive impact on profitability and increases in labour productivity. Information systems investments however, can also have negative impact on banking operations. For this reason, the strategic staff respondents were asked to ascertain the positive impact of IS investments in banks. The researcher presents the responses of the strategic staff by banks in Table 3 . 
Table 3: Responses on Effect of IT/IS Investment on Bank Performance

\begin{tabular}{|c|c|c|c|c|c|c|c|c|c|c|c|c|}
\hline \multirow[t]{2}{*}{$\mathbf{N}=32$} & \multicolumn{2}{|c|}{ Bank A } & \multicolumn{2}{|c|}{ Bank B } & \multicolumn{2}{|c|}{ Bank C } & \multicolumn{2}{|c|}{ Bank D } & \multicolumn{2}{|c|}{ Bank E } & \multicolumn{2}{|c|}{ Bank F } \\
\hline & Freq & $\%$ & Freq & $\%$ & Freq & $\%$ & Freq & $\%$ & Freq & $\%$ & Freq & $\%$ \\
\hline $\begin{array}{l}\text { Reduces operating } \\
\text { expenses }\end{array}$ & 1 & 16.7 & 1 & 16.7 & 1 & 20.0 & - & - & - & & - & \\
\hline $\begin{array}{l}\text { Increase market } \\
\text { share of deposits }\end{array}$ & 2 & 33.3 & 2 & 33.3 & 1 & 20.0 & 1 & 20.0 & 1 & 20.0 & 1 & 20.0 \\
\hline Increase profits & 2 & 33.3 & 2 & 33.3 & 2 & 40.0 & 2 & 40.0 & 2 & 40.0 & 2 & 40.0 \\
\hline $\begin{array}{l}\text { Positive impact on } \\
\text { Return on Asset }\end{array}$ & 1 & 16.7 & 1 & 16.7 & 1 & 20.0 & 1 & 20.0 & 1 & 20.0 & 1 & 20.0 \\
\hline $\begin{array}{l}\text { Increases labour } \\
\text { Productivity }\end{array}$ & - & - & - & - & - & - & 1 & 20.0 & 1 & 20.0 & 1 & 20.0 \\
\hline Total & 6 & 100.0 & 6 & 100.0 & 5 & 100.0 & 5 & 100.0 & 5 & 100.0 & 5 & 100.0 \\
\hline
\end{tabular}

Source: Field data, 2015

On the impact of IT investments on key variables, the above table indicates that all the banks (both foreign and local) asserted that market share, profitability, and ROA increases as IT investment are employed in the industry. This supports the school of thought that banks that invest heavily in technology would have an increase in market share of deposits and loans. In addition, the foreign banks indicated increased labour productivity as one of the key variables on IS investments whilst the local banks also indicated reduction in operating expenses. This expected impact of IS investments is a sure motivator for the employment of the state of the art technology which banks are heavily dependent on to survive in the face of keen competition.

\section{Hypothesis Testing}

Hypothesis is a specific statement of prediction. It describes in concrete terms what the expectation will be in the study. A single study may have one or many hypotheses (Ankrah, 2013). In this study, the researcher employs the chi-square test to test the relationship between two variables. The specific hypothesis is stated before conducting the test. The researcher identifies Ho with the null hypothesis and Ha with the research hypothesis (alternative hypothesis).

Ho: Information systems investment does not have a positive relationship with bank performance.

Ha: Information systems investment has a positive relationship with bank performance.

\section{Critical value}

From the chi square distribution, a significance level of 0.05 with two degrees of freedom gives a critical value of 5.99 . 


\section{Decision rule}

The researcher cannot accept Ho, if chi-square calculated is greater than 5.99 and concludes that, Information systems investment has a positive relationship with bank performance else the researcher will fail to reject Ho and conclude that, information systems investment does not have a positive relationship with bank performance.

\section{Test Statistic}

Suppose that there are I rows and J columns, let $P_{i .}$ and $P_{. j}$ be their respective marginal probabilities. Then $\mathrm{p}_{\mathrm{ij}}=\mathrm{P}_{\mathrm{i} .}{ }^{*} \mathrm{P}_{\mathrm{j} j}$ and $\mathrm{E}_{\mathrm{ij}}=\mathrm{n}^{*} \mathrm{p}_{\mathrm{ij}}$ Let $\mathrm{T}_{\mathrm{i}}=$ Total for row $\mathrm{i}$ and $\mathrm{T}_{\mathrm{j}}=$ Total for column $\mathrm{j}$

Then $P_{i .}=\frac{T i}{n}$ and $\quad P_{. j}=\frac{T j}{n}$

Where $\mathrm{n}=$ Total number of observations

$\mathrm{P}_{\mathrm{ij}}=$ Propability of the ith row and jth column

$E_{i j}=$ Expected Value of the ith row and jth column

The test statistic is a chi square, $\chi^{2}$ with $(\mathrm{I}-1)^{*}(\mathrm{~J}-1)$ degrees of freedom.

$\chi^{2} \mathrm{cal}=\sum_{\mathrm{i}=1}^{\mathrm{I}} \sum_{\mathrm{j}=1}^{\mathrm{J}} \frac{\left(\mathrm{O}_{\mathrm{ij}}-\mathrm{E}_{\mathrm{ij}}\right)^{2}}{\mathrm{E}_{\mathrm{ij}}}$ with $\mathrm{df}=(\mathrm{I}-1) *(\mathrm{~J}-1)$

Where Oij are the observed values

Eij are the expected values and

$\mathrm{df}$ is the degrees of freedom

Table 4: Observed and Expected Values of Bank Performance by IS Investment

\begin{tabular}{|c|c|c|c|c|c|c|}
\hline & \multirow{2}{*}{$\mathbf{N}=32$} & & \multicolumn{3}{|c|}{ IS Investments } & \multirow[b]{2}{*}{ Total } \\
\hline & & & Low & Moderate & High & \\
\hline \multirow[t]{4}{*}{ Bank Performance } & Moderate & Count & 2 & 0 & 6 & 8 \\
\hline & & Expected Count & .5 & 2.5 & 5.0 & 8.0 \\
\hline & High & Count & 0 & 10 & 14 & 24 \\
\hline & & Expected Count & 1.5 & 7.5 & 15.0 & 24.0 \\
\hline \multirow[t]{2}{*}{ Total } & & Count & 2 & 10 & 20 & 32 \\
\hline & & Expected Count & 2.0 & 10.0 & 20.0 & 32.0 \\
\hline
\end{tabular}

$\mathrm{N}=32 \quad$ Chi Square $=9.600 \quad \mathrm{DF}=2 \mathrm{p}$-value $=0.000 \quad$ COR $=0.559$

Source: Field data, 2015

The chi-square calculated is equal to 9.600 and the critical value is equal to 5.99. Since the chisquare calculated is greater than the critical value and $p$-value $=0.000$, thus, Ho cannot be accepted. Therefore, information systems investment has a positive relationship with bank performance. This is further strengthened by a correlation coefficient of 0.559 .

\section{CONCLUSION}

Technology has brought about a complete paradigm shift in the functioning of banks and delivery of banking services. The growth of the internet, mobiles and communication technology has added a different dimension to banking. The information technology (IT) available today is being leveraged in customer acquisitions, driving automation and process efficiency, delivering ease and efficiency to customers. There is a growing debate in the business community about the importance of measuring the return on investments in IS. This 
is a difficult and challenging task, given that many of the benefits derived from IS are both intangible and long term. In spite of the limitations of existing productivity measures, it is important to monitor and assess the contribution of IS investments to organizational productivity and efficiency. Banks that do not make investments that take advantage of new technology may find that they are losing customers to the better-quality or lower-cost products of firms that do. But using IT as a strategic weapon can be quite tricky, entailing high costs and an uncertain payoff (Brynjolfsson and Hitt, 2001).

The advancement of technology is a necessity of the current era. Businesses need to adopt and embrace new technologies to provide excellent business operations and services to their customers. The banking industry is not an exception with regards to this adaptation. So it is worth suggesting that the banking industry needs to spend more on IT and better apply IT to improve its operations, customer services and products. Banks should devote more resources to the development of secure IT systems, services and products. The local banks must invest more in IS especially, in IT security and IT infrastructure to achieve better results. Bank C must also conduct a systems audit to know the true picture of the system. Further research into the analysis of the individual IS strategy of the banks to determine whether it conforms to IS standards would be a vital venture.

\section{References}

Agboola, A. A. (2003). Information technology, bank automation, and attitude of works in Nigerian banks. In Journal of Social Sciences.

Allen, J., Engert, W., \& Ying, L. (2006). Are Canadian Banks Efficient? A Canada -U.S. comparison, Bank of Canada working paper 2006-33,

Alpar, P., \& Kim, M. (1991). "A microeconomic approach to the measurement of information technology value". Journal of Management Information Systems, 7(2), 55-69.

Ankrah, E. (2013). Customer Satisfaction of Electronic Products and Services in Ghanaian Banks.

Information and Knowledge Management, 3(1), 7-18.

Barua, A., Kriebel, C., \& Mukhopadhyay, T. (1991). Information technology and business value: An analytic and empirical investment, University of Texas at Austin Working Paper.

Beccalli, E. (2007). Does IT investment improve bank performance? Evidence from Europe. Journal of Banking \& Finance, 31(7), 2205-2230.

Bruque, S. N., Vargas, A., \& Hernandez, M. J. (2002). Influence of the internet use of firm performance; An application to the pharmaceutical distribution industry in Spain. Gdansk, Poland: ECIS.

Brynjolfsson, E., Hitt, L., \& Yang, S. (2000). Intangible assets: How the interaction of computers and organizational structure affects stock market valuations. MIT Working paper. Retrieved from

http://ecommmerce.mit.edu/erik/index.html

Brynjolfsson, E., \& Hitt, L. (2001). "Information technology as a factor of production: The role of difference among firms", Economics of Innovation and New Technology, 3, 183-199.

Creswell, J. (2003). Research design: qualitative, quantitative and mixed Methods approaches (2nd ed.). London: Sage publications.

DeLone, W. H., \& McLean, E. R. (2003). The DeLone and McLean model of information systems success: A ten-year update, Journal of Management Information Systems, Vol. 19 No. 4, pp. 9-30.

Franke, R. H. (1987). Technological revolution and productivity decline: Computer introduction in the financial industry. Technological Forecasting and Social Change, 33, 143-154.

Gupta, U. G. \& Collins, W. (1997). The impact of information systems on the efficiency of banks: an empirical investigation, Industrial Management \& Data Systems, MCB university press.

Harris, S. E., \& Katz, J. (1991). “Organizational performance and information technology investment intensity in the insurance industry", Organization Science, 2(3), 263-296. 
Hitt, L., and Brynjolfsson, E. (1996). Productivity, business profitability, and consumer surplus: Three different measures of information technology value. MIS Quarterly, 20(2), 121-142.

Karimi, J., Gupta, Y. P., \& Somers, T. M. (1996). Impact of competitive strategy and information technology maturity on firms' strategic response to globalization. Journal of Management Information Systems, 12(4), 55-88.

Konsynski, B. R. (1993). "Strategic Control in the Extended Enterprise," IBM Systems Journal, 32(1).

Lee, R. C. (2012). Does the success of information systems really matters to firm performance. iBusiness, 98-107.

Mitra, S., \& Chaya, A. K (1996). "Analyzing cost-effectiveness of organizations: the impact of information technology spending", Journal of Management Information Systems, 13(2), 29-57.

Morton, S. M. (ed), (1991). The Corporation of the 1990s: Information Technology and Organizational Transformation.

Parsons, D. J., Gotlieb, C. C., \& Denny, M. (1990). Productivity and computers in Canadian banking. University of Toronto Department of Economics, Working Paper No. 9012.

Pehlivan, H., \& Kirpatric, C. (1990). The impact of transactional banks on developing countries' banking sector: An analysis of the Turkish experience, 1980-89.

Pitt, L. F., Parent, M., Junglas, I., Chan, A., \& Spyropoulou, S. (2011). Integrating the Smartphone into a sound environmental information systems strategy: Principles, practices and a research agenda. The Journal of Strategic Information Systems, 20(1), 27-37.

Pulley, L. B., \& Braunstein, Y. M. (1984), Scope and scale augmenting technological change: An application in the information sector. North-Holland, Juswalla and Ebedfield.

Reixach, A. A. (2001). The effects of information and communication technology on the banking sector and payments system (PhD Thesis). Universitat de Girona.

Robson, W. (1997). Strategic Management and Information Systems, Pitman.

Shareef, M. A., Kumar, V., Kumar, U. \& Dwivedi, Y. K. (2011). E-Government adoption model (GAM): Differing service maturity levels. Government Information Quarterly, 28(1), 17-35.

Strassmann, P. A. (1997). The squandered computer: Evaluating the business alignment of information technology. The Information Economic Press.

The Reporter, Ghana (2014, January), 224-234.

Tsai, W. H., Lee, P. L., Shen, Y. S., \& Lin, H. L. (2012), A comprehensive study of the relationship between enterprise resource planning selection criteria and enterprise resource planning system success, Information \& Management, 49(1), 36-46.

Woherem, E. W. (2000). Information technology in the Nigeria banking industry. Ibadan, Spectrum. 